\title{
Boron fertilizing management on fruit production and quality of mango cv. Palmer in semiarid
}

\author{
Fernanda Campos Alencar Oldoni ${ }^{1}$, Augusto Miguel Nascimento Lima ${ }^{2}$, \\ Ítalo Herbert Lucena Cavalcante ${ }^{3}$, Karla dos Santos Melo de Sousa ${ }^{4}$, \\ Marcio Alves Carneiro 5 , Itamara Rayanny Bessa de Carvalho ${ }^{6}$
}

\begin{abstract}
Adequate fertilizing management is crucial to reach high mango yields that demand a well-defined fertilizer management, including micronutrient such as boron which management is more difficult due to the narrow range between deficiency and toxicity. This way, an experiment was carried out to evaluate the fruit production and quality of mango cv. Palmer as a function of boron fertilizing management in Brazilian semiarid. The experimental design was in randomized blocks with six treatments (strategies for boron fertilizing), as follows: $11=$ five sprays with $\mathrm{H}_{3} \mathrm{BO}_{3}$ (two first at $0.3 \%$ and three at $0.2 \%$ ); $\mathrm{T} 2$ = five sprays with $\mathrm{H}_{3} \mathrm{BO}_{3}$ (two first at $0.3 \%$ and three at $0.4 \%$ ); $\mathrm{T} 3=$ five sprays with $\mathrm{H}_{3} \mathrm{BO}_{3}$ (two first at $0.3 \%$ and three at $0.6 \%$ ); $\mathrm{T} 4=$ two

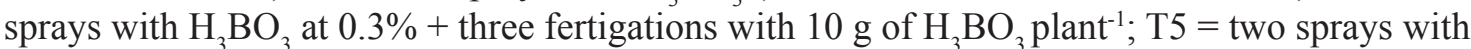
$\mathrm{H}_{3} \mathrm{BO}_{3}$ at $0.3 \%$ + three fertigations with $20 \mathrm{~g}$ of $\mathrm{H}_{3} \mathrm{BO}_{3}$ plant ${ }^{-1}$; and $\mathrm{T} 6=$ two sprays with $\mathrm{H}_{3} \mathrm{BO}_{3}$ at $0.3 \%+$ three fertigations with $40 \mathrm{~g}$ of $\mathrm{H}_{3} \mathrm{BO}_{3}$ plant $^{-1}$. Boron fertilizing management (foliar spray and fertigation) affects fruit production and quality of mango cv. 'Palmer' grown in semiarid. According to the minimum quality criteria required for mango fruit commercialization and the fruit production per plant in semiarid, five sprays with $\mathrm{H}_{3} \mathrm{BO}_{3}$ [two first at $0.3 \%$ and three at $0.2 \%$ ] could be recommended.
\end{abstract}

Index terms: Mangifera indica L. fertilization, fertirrigation, boron.

\section{Manejo da adubação boratada na produção e na qualidade de frutos de manga cv. Palmer no semiárido}

\begin{abstract}
Corresponding author:
fernandac.alencar2010@gmail.com

Received: April 17, 2017.

Accepted : November 16, 2017.

Copyright: All the contents of this journal, except where otherwise noted, is licensed under a Creative Commons Attribution License.
\end{abstract}

\section{(cc) $\mathrm{EY}$}

Resumo - O adequado manejo de adubação boratada é crucial para elevadas produtividades que demandam manejo de fertilizantes bem definido, inclusive de micronutrientes, como o boro, cujo manejo é difícil devido à estreita faixa entre deficiência e toxicidade. Nesse sentido, um experimento foi desenvolvido com o objetivo de avaliar a produção e a qualidade de frutos de manga cv. Palmer em função do manejo de adubação boratada no semiárido. Adotou-se delineamento em blocos casualizados, com seis tratamentos (estratégias de adubação borratada), como segue: $\mathrm{T} 1$ = cinco pulverizações com $\mathrm{H}_{3} \mathrm{BO}_{3}$ [duas primeiras $(0,3 \%)$ e demais $(0,2 \%)$ ]; T2 = cinco pulverizações com $\mathrm{H}_{3} \mathrm{BO}_{3}$ [duas primeiras $(0,3 \%)$ e demais $(0,4 \%)$ ]; $\mathrm{T} 3=$ cinco pulverizações com $\mathrm{H}_{3} \mathrm{BO}_{3}$ [duas primeiras $(0,3 \%)$ e demais $(0,6 \%)]$; $\mathrm{T} 4=$ duas pulverizações com $\mathrm{H}_{3} \mathrm{BO}_{3}(0,3 \%)+$ três fertirrigações $\left(10 \mathrm{~g} /\right.$ planta $^{-1}$ de $\left._{3} \mathrm{BO}_{3}\right)$; T5 = duas pulverizações com $\mathrm{H}_{3} \mathrm{BO}_{3}(0,3 \%)+$ três fertirrigações $(20 \mathrm{~g} /$ planta $^{-1}$ de $\left._{3} \mathrm{BO}_{3}\right) ; \mathrm{T} 6=$ duas pulverizações com $\mathrm{H}_{3} \mathrm{BO}_{3}(0,3 \%)+$ três fertirrigações $\left(40 \mathrm{~g} / \mathrm{planta}^{-1}\right.$ de $\mathrm{H}_{3} \mathrm{BO}_{3}$ ). Há influência da forma de fertilização boratada (pulverização foliar e fertirrigação) na produção e na qualidade de frutos de manga cv. 'Palmer'. Considerando os critérios mínimos de na qualidade exigidos para comercialização de manga no Brasil e a produção por planta, nas condições edafoclimáticas do experimento, podem-se recomendar cinco pulverizações com $\mathrm{H}_{3} \mathrm{BO}_{3}$ [duas primeiras $0,3 \%$ e demais $0,2 \%$ ].

Termos para indexação: Mangifera indica L., fertilização, fertirrigação, boro. 


\section{Introduction}

São Francisco Valley, especially in Petrolina and Juazeiro counties, accounts for $85 \%$ of Brazilian exports of fresh mango (VALEXPORT, 2016), which contributes to Brazil be one of the largest mango exporter countries, with almost $10 \%$ of the world mango market (FAO, 2014), therefore with significant economic and social importance for Brazil.

Mango plant requires high amounts of macro and micronutrients, although micronutrient management is more difficult due to the narrow range between deficiency and toxicity that can occur for most crops (PRADO, 2004). Additionally, balanced fertilization, especially in relation to boron is necessary for mango production in high yields and with the quality demanded by the most exigent markets (SARAN; KUMAR, 2011).

Boron in the soil solution is found in the soluble fraction as boric acid $\left(\mathrm{H}_{3} \mathrm{BO}_{3}\right)$ which reaches plant roots through mass flow (MATTIELLO et al., 2009). This fraction has its availability strongly affected by organic matter content, soil $\mathrm{pH}$ and soil clay proportion, besides the B loss by leaching (WÓJCIK et al., 2008).

In plant, boron stimulates pollen grain germination and pollen tube growth (LEE et al., 2009), a key factor for adequate fruit formation, besides being related to carbohydrate transport and metabolism, facilitating sugar transport as borate-sugar complex through membranes (DECHEN; NACHTIGALL, 2006), besides being an important constituent nutrient of polysaccharide structure responsible for cell wall resistance, thus resulting in more resistant fruits during post-harvest (TAIZ; ZEIGER, 2009).

In the scientific literature it is possible to find research manuscript about boron effects on mango but there is no consensus about what supply strategy is the best for mango crop. Galli et al. (2013) studied boron fertilization for 36 mango cultivars and observed boron positive effect on fruit production and quality, including for cv. Palmer, with an increase from 219 fruits plant $^{-1}$ (without boron fertilizing) to 246.5 fruits plant ${ }^{-1}$ (with boron fertilizing), while for other mango cultivars there was increase of fruit mass and soluble solids content; Barbosa et al. (2016) evaluated boron fertilizing strategies also in Semiarid climate and concluded that boron fertilizing management affects fruit yield of mango cv. Palmer reaching $35.62 \mathrm{t} \mathrm{ha}^{-1}$; Ali et al. (2017) studied boron fertilizing in Egypt and recorded fruit yield increase from $103.90 \mathrm{~kg}$ plant ${ }^{-1}$ to $104.27 \mathrm{~kg} \mathrm{plant}^{-1}$ as a function of $\mathrm{H}_{3} \mathrm{BO}_{3}$ spray at $0.3 \%$; also in Egypt Baiea et al. (2015) recorded higher average values of soluble solids and ascorbic acid for fruit from plants fertilized with $200 \mathrm{mg}$ of $\mathrm{H}_{3} \mathrm{BO}_{3} \mathrm{~L}^{-1}$; In Pakistan, Anees et al. (2011) registered that plants sprayed with $\mathrm{H}_{3} \mathrm{BO}_{3}$ at $0.8 \%$ produced fruits with higher soluble solids and ascorbic acid.
It detaches that fruit post-harvest quality depends on several factors such as plant genetics, climate and production system used in the field, including irrigation management and especially fertilizer management which affects plant nutrition directly (MOTTA et al., 2015).

Hence, the present study aimed to evaluate the fruit production and quality of mango cv. Palmer as a function of boron fertilizing management in Brazilian semiarid.

\section{Material and Methods}

\section{Plant Material and Growth Conditions}

Mango (Mangifera indica L.) plants cv. Palmer with uniform size and vigor, that were eleven years old, were used in this study.

The study was conducted from 2013 to 2014 in an experimental orchard located in Herculano Agrícola farm in Casa Nova County ( $09^{\circ} 11^{\prime} \mathrm{S}$ and $41^{\circ} 59^{\prime} \mathrm{W}$; at an altitude of $400.3 \mathrm{~m}$ above sea level), Bahia State, Brazil. The climate of this region is classified as Bswh (Köeppen), which corresponds to a semiarid region. During the execution of the experiment the average air temperature and air humidity ranged from $20.7{ }^{\circ} \mathrm{C}$ to $35.4{ }^{\circ} \mathrm{C}$ and from $61.4 \%$ and $88.7 \%$, respectively, with accumulated precipitation of $194.8 \mathrm{~mm}$.

Before the experiment 20 soil samples were collected at $0-40 \mathrm{~cm}$ depth for soil for physical and chemical characterization, following Silva (2009) methodology (Table 1). Specifically for boron (Table 1), the initial soil average value was below the critical level stated to mango which is $0.5 \mathrm{mg} \mathrm{dm}^{-3}$ (MENGEL et al., 2001) or $0.6 \mathrm{mg} \mathrm{dm}^{-3}$ (ALVAREZ V. et al., 1999).

The plants, spaced with $7 \mathrm{~m}$ between the rows and 7 $\mathrm{m}$ between the plants, were daily irrigated (micro sprinkler) with one emitter per plant, for a flow of $60 \mathrm{~L} \mathrm{~h}^{-1}$. All management practices such as pruning, control of weeds, pests and diseases, plant growth regulators for gibberellin inhibition (Cultar ${ }^{\circledR}$ ) and break dormancy (calcium nitrate) were performed following the instructions of Genú e Pinto (2002). The nutrient management was performed through a fertirrigation system, according to soil analysis (Table 1) and plant demand (GENÚ e PINTO, 2002).

\section{Treatments and Experimental Design}

The experimental design consisted of randomized blocks with six treatments, four replications and two plants in each parcel. Treatments consisted of six strategies for boron fertilizing, as follows: $\mathrm{T} 1=$ five sprays with $\mathrm{H}_{3} \mathrm{BO}_{3}$ (two first at $0.3 \%$ and three at $0.2 \%$ ); $\mathrm{T} 2=$ five sprays with $\mathrm{H}_{3} \mathrm{BO}_{3}$ (two first at $0.3 \%$ and three at $0.4 \%$ ); T3 = five sprays with $\mathrm{H}_{3} \mathrm{BO}_{3}$ (two first at $0.3 \%$ and three at $0.6 \%$ ); T4 $=$ two sprays with $\mathrm{H}_{3} \mathrm{BO}_{3}$ at $0.3 \%+$ three fertigations with $10 \mathrm{~g}$ of $_{3} \mathrm{BO}_{3}$ plant $^{-1}$; $\mathrm{T} 5=$ two sprays with $\mathrm{H}_{3} \mathrm{BO}_{3}$ at $0.3 \%$ + three fertigations with $20 \mathrm{~g} \mathrm{of}_{3} \mathrm{BO}_{3}$ plant $^{-1}$; and $\mathrm{T} 6=$ two sprays with $\mathrm{H}_{3} \mathrm{BO}_{3}$ at $0.3 \%+$ three fertigations with 
$40 \mathrm{~g}$ of $\mathrm{H}_{3} \mathrm{BO}_{3}$ plant $^{-1}$. Treatments were defined following plant demands according to Genú e Pinto (2002) and soil analysis (Table 1). These treatments were performed when panicles were recently emitted (nearly at seven days after panicle emission).

Table 1.Chemical characteristics of the soil $(0-40 \mathrm{~cm}$ soil depth) where the experiment was carried out.

\begin{tabular}{ccccccccc}
\hline $\begin{array}{c}\mathrm{ECse} \\
\left(\mathrm{dS} \mathrm{m}^{-1}\right)\end{array}$ & $\begin{array}{c}\mathrm{OM} \\
\left(\mathrm{g} \mathrm{kg}^{-1}\right)\end{array}$ & $\mathrm{pH}\left(\mathrm{H}_{2} \mathrm{O}\right)$ & $\begin{array}{c}\mathrm{P} \\
\left(\mathrm{mg} \mathrm{dm}^{-3}\right)\end{array}$ & & $\mathrm{K}^{+}$ & $\mathrm{Ca}^{2+}$ & $\begin{array}{c}\mathrm{Mg}^{2+} \\
\left(\mathrm{cmol} \mathrm{dm}^{-3}\right)\end{array}$ & $\mathrm{Na}^{+}$ \\
\hline 0.30 & 19.00 & 6.50 & 36.00 & 0.32 & 4.30 & 1.20 & 0.05 \\
\cline { 1 - 6 } $\mathrm{H}+\mathrm{Al}$ & $\begin{array}{c}\mathrm{CEC} \\
\left(\mathrm{cmol}_{c} \mathrm{dm}^{-3}\right)\end{array}$ & $\mathrm{Al}^{3+}$ & $\begin{array}{c}\mathrm{V} \\
(\%)\end{array}$ & $\mathrm{Cu}$ & $\mathrm{Fe}$ & $\begin{array}{c}\mathrm{Mn} \\
\left(\mathrm{mg} \mathrm{dm}^{-3}\right)\end{array}$ & $\mathrm{Zn}$ & $\mathrm{B}$ \\
\hline 0.96 & 6.83 & 0.00 & 86.00 & 0.60 & 3.10 & 33.00 & 49.80 & 0.40 \\
\hline
\end{tabular}

"ECse: Electrical conductivity of the saturation extract; P, K: Mehlich 1; H + Al: calcium acetate (extractor) 0.5 M, pH 7; Al, Ca, Mg: KCl 1 M extractor; CEC: cationic exchangeable capacity; OM: organic matter. (Silva, 2009)

\section{Data Gathered and Statistical Analysis}

According to recommendations of Silva (2009) leaf samples were collected at full flowering in the middle part of the canopy in branches with flowers to perform the boron nutritional analysis. Leaves were chemically analyzed after they were washed and rinsed with distilled water and dried at $65^{\circ} \mathrm{C}$ until reach constant weight following methodology described by Silva (2009).

Fruit production per plant was measured using a Filizola ${ }^{\circledR}$ CF15 brand precision scale (0.5 grams of precision) and expressed in kilograms per plant $\left(\mathrm{kg} \mathrm{plant}^{-1}\right)$. Commercial fruits were manually harvested in a single day when they reached the minimum size of $15 \mathrm{~cm}$ and physiological maturity which was characterized through pulp color (yellow cream), following the fruit selection parameter recommended by the Brazilian Program for Horticulture Modernization (2004) for commercial farms. After the registration of fruit production per plant the fruit yield $\left(\mathrm{t} \mathrm{ha}^{-1}\right)$ was calculated. The number of commercial fruits (fruits plant ${ }^{-1}$ ) was also recorded.

The fruit analyses of the mango fruits followed the instructions of Zenebon et al. (2008) and included the usual parameters: i) the fruit mass was measured using a Sartorious ${ }^{\circledR}$ (Göttingen, Germany) brand precision balance ( $0.01 \mathrm{~g}$ precision) and expressed in $\mathrm{g}$; ii) length and width were obtained with a digital paquimeter $(0.01 \mathrm{~mm}-300$ $\mathrm{mm}$, Starret ${ }^{\mathbb{R}}$ ) and expressed in $\mathrm{cm}$; iii) for the titratable acidity (TA), $20 \mathrm{~g}$ of macerated fruit pulp was taken from yellow passion fruits and brought to a final volume of 100 $\mathrm{mL}$ by adding distilled water. A $20 \mathrm{~mL}$ sample was taken from the mixture; and three to four drops of phthalein were used as an indicator. This suspension was titrated with 0.1 $\mathrm{N}$ sodium hydroxide $(\mathrm{NaOH})$. The results were expressed as a percentage; iv) the soluble solids (SS), expressed as ${ }^{\circ}$ Brix, were measured using an $\mathrm{Abbe}^{\circledR}$ refractometer (Bausch and Lomb, Rochester, NY, USA); v) The vitamin $\mathrm{C}$ content was defined with $5 \mathrm{~g}$ of fruit pulp taken from mango and brought to a final volume of $100 \mathrm{~mL}$ by adding distilled water plus $1 \mathrm{~mL}$ of $1 \%$ amid solution. A $20 \mathrm{~mL}$ sample was taken from the mixture and titrated with $1 \mathrm{~N}$ iodine. The results were expressed in $\mathrm{mg} 100 \mathrm{~g}^{-1}$ of fresh fruit; vi) the pulp $\mathrm{pH}$ was measured using a Marconi ${ }^{\circledR} \mathrm{pH}$ meter; vii) after chemical analyses, the relation between the soluble solids and the titratable acidity (SS/TA ratio) and pulp percentage were calculated.

Statistical analyses included analysis of variance (ANOVA) using combined data from 2013 and 2014. All calculations were performed using the ASSISTAT 7.7 software, and terms were considered significant at $p$ $<0.01$.

\section{Results and Discussion}

In the present study, leaf boron concentrations (B) ranged from 216 to $311 \mathrm{mg} \mathrm{kg}^{-1}$ (Figure 1A), thus above the stated adequate range of supply (50 to $100 \mathrm{mg} \mathrm{kg}^{-1}$ ), defined by Genú and Pinto (2002), although no visual symptom of B toxicity has been observed. In this sense, Barbosa et al. (2016) clarify that most of interpretation tables for macro and micronutrient were developed for non-irrigated conditions, showing the need of research studies aimed at the establishment of B availability classes under irrigation conditions, especially for semiarid regions where the soil and climate conditions are peculiar. In a study carried out in India, Saran and Kumar (2011) observed that foliar sprays of boron $(0,10 \%$ of disodium octborate tetrahydrate) were most effective in increasing the level of B in leaf and fruits (149.64\% and $120.14 \%$, respectively) of 'Dashehari' cultivar, with higher efficiency for leaf spray fertilizing. Also in India, Raja et al. (2005) recorded increased of B leaf concentration from 23 to 67 $\mathrm{mg} \mathrm{kg}^{-1}$ as a function of leaf B sprays.

Fruit production per plant depended on boron fertilizing management evaluated, ranging from 104.24 $\mathrm{kg} \mathrm{plant}^{-1}$ (T3) to $151.64 \mathrm{~kg} \mathrm{plant}^{-1}$ (T1 treatment) (Figure 1B). The statistical higher fruit production was recorded only for those treatments sprayed with the lowest B doses, showing that small well-distributed B quantities are sufficient for mango production in semiarid in the amount of initial boron in the soil of $0.40 \mathrm{mg} \mathrm{dm}^{-3}$. On the other hand, Galli et al. (2013) evaluated the effects of B fertilizing on mango 'Palmer' in São Paulo (Brazil) 
and registered fruit production increasing of $12.6 \%$ for $\mathrm{B}$ fertilized plants, that is in agreement with Bhatt et al. (2012), who verified that mango plants cv. 'Dashehari' produced $28.82 \mathrm{~kg} \mathrm{plant}^{-1}$ more when sprayed with $0.5 \%$ borax. The highest fruit production per plant recorded in this study (T1) is higher than the best result $\left(137 \mathrm{~kg} \mathrm{plant}^{-1}\right)$ reported by Cavalcante et al. (2016) for mango 'Palmer' also grown in semiarid condition.
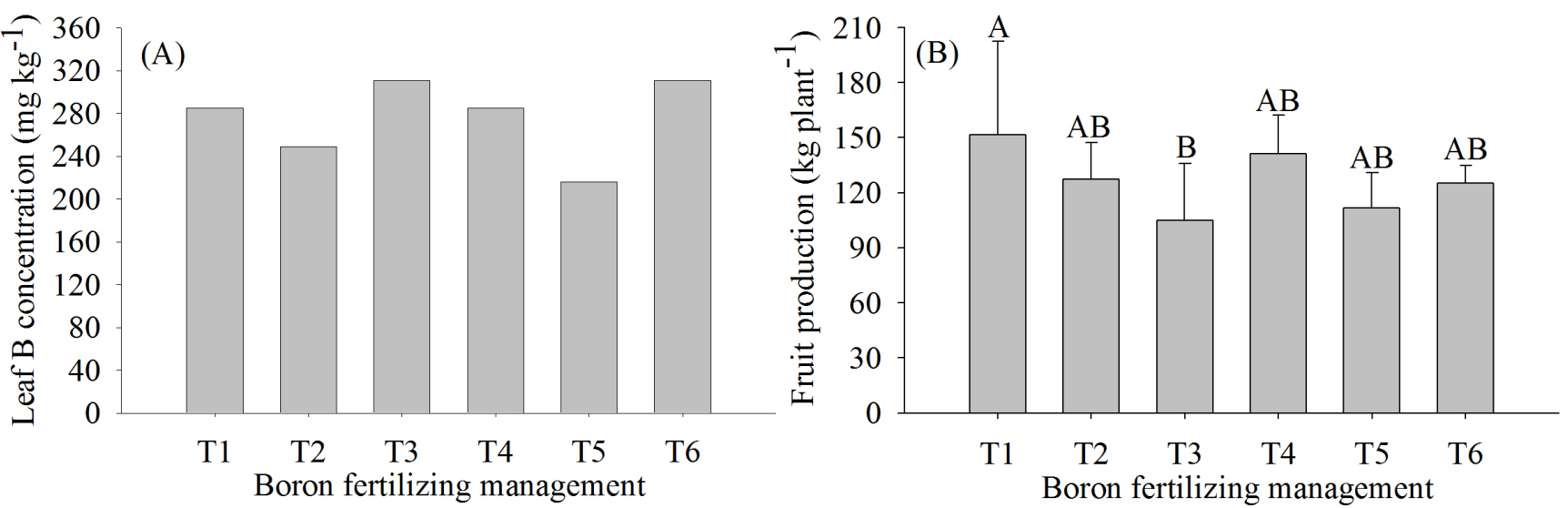

Figure 1. Boron leaf concentration (A) and fruit production (B) of mango cv. Palmer as a function of boron fertilizing management.

${ }^{(1)}$ Bars with the same capital letters do not differ in among themselves by Tukey's test at $1 \%$ probability. T1 = five sprays with $\mathrm{H}_{3} \mathrm{BO}$ ( at $0.2 \%$ ); $\mathrm{T} 2=$ five sprays with $\mathrm{H}_{3} \mathrm{BO}_{3}$ (two first at $0.3 \%$ and three at $0.4 \%$ ); $\mathrm{T} 3=$ five sprays with $\mathrm{H}_{3} \mathrm{BO}_{3}$ (two first at $0.3 \%$ and three at $0.6 \%$ ); $\mathrm{T} 4=$ two sprays

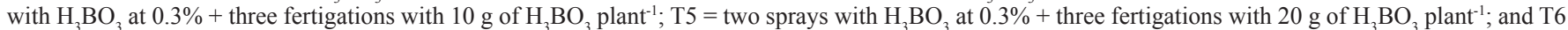
$=$ two sprays with $\mathrm{H}_{3} \mathrm{BO}_{3}$ at $0.3 \%+$ three fertigations with $40 \mathrm{~g}$ of $\mathrm{H}_{3} \mathrm{BO}_{3}$ plant ${ }^{-1}$.

The fruit length and width (Figures 2A and 2B) were affected by B fertilizing management slightly, however, in general, treatments with five $\mathrm{H}_{3} \mathrm{BO}_{3}$ leaf sprays presented the higher absolute values detaching T3 which presented $13.77 \mathrm{~cm}$ (fruit length) and $8.99 \mathrm{~cm}$ (fruit width), values higher than those reported by Silva et al. (2014) for 'Palmer' grown in São Paulo, Brazil. Accordingly, boron has limited mobility in most plant species, thus it accumulates in older leaves because they transpire more than flowers and fruits, and also participate directly in pollination process (GALLI et al., 2012), and its foliar application complements could supply B demand of these plant organs (BARBOSA et al., 2016), resulting in increased fruit diameter.

The fruits produced by plants treated with five leaf sprays of $\mathrm{H}_{3} \mathrm{BO}_{3}$ also presented higher fruit mass, with $550.08 \mathrm{~g}$ (T1), $524.31 \mathrm{~g}$ (T2) and $569.95 \mathrm{~g}$ (T3) (Figure 2C) that, according to the classification established by the Brazilian Program for Horticulture Modernization (2005), are classified in the $551-800$ g class, while fruits produced in T4 (487.94 g), T5 (460.04 g) and T6 treatments $(482.72 \mathrm{~g})$, are in the $351 \mathrm{~g}-550 \mathrm{~g}$ class. Silva et al. (2012b) verified a similar average of fruit mass for 'Palmer' (562.4 g) in Minas Gerais state (Brazil). It is important to note that boron promotes better formation of plant tissue, thus increasing fruit mass (CHITARRA; CHITARRA, 2005).

Pulp percentage (Figure 2D) were affected slightly by $\mathrm{B}$ fertilizing management, however, plants treated with five $\mathrm{H}_{3} \mathrm{BO}_{3}$ leaf sprays (T2), it is recorded higher pulp percentage average (70.33\%) than T3, T4 and T6. According to Chitarra and Chitarra (2005), pulp percentage is an important variable for fruits produced specifically for juice or pulp industries, since it indicates the relative revenue of the commercial product.

As can be seen in Figure 2E, the B fertilizing management treatments had no significant effect on fruit skin thickness, with average values ranging from 19.7 to $23.3 \mathrm{~mm}$. Maurer and Taylor (1999) evaluated the effect B leaf spray on orange quality in Sun City, USA, and also verified no effect on juice concentration nor the skin thickness, although the B contents in the leaves increased.

Chemical fruit quality results of mango 'Palmer' as a function of B fertilizing management are in Figure 3, where it is verified that the $\mathrm{T} 2$ treatment presented higher titratable acidity (TA) $\left(0.27 \mathrm{~g}\right.$ citric acid $100 \mathrm{~g}^{-1}$ of pulp) than other evaluated treatments. Carvalho et al. (2004) registered average TA values range $0.07-0.3 \mathrm{~g}$ citric acid $100 \mathrm{~g}^{-1}$ of pulp in mature fruits of mango cv. Palmer, whereas Silva et al. (2012b) reported $0.20 \mathrm{~g}$ citric acid 100 $\mathrm{g}^{-1}$ of pulp also for cv. Palmer. According to the mango fruit quality and identity standards established by Ministry of Agriculture, Livestock and Food Supply (Brasil, 2000), the AT values of the present study ( 0.16 to $0.27 \mathrm{~g}$ citric acid $100 \mathrm{~g}^{-1}$ of pulp) are within the established quality standard (maximum of $0.32 \%$ citric acid), independently of the treatment. 

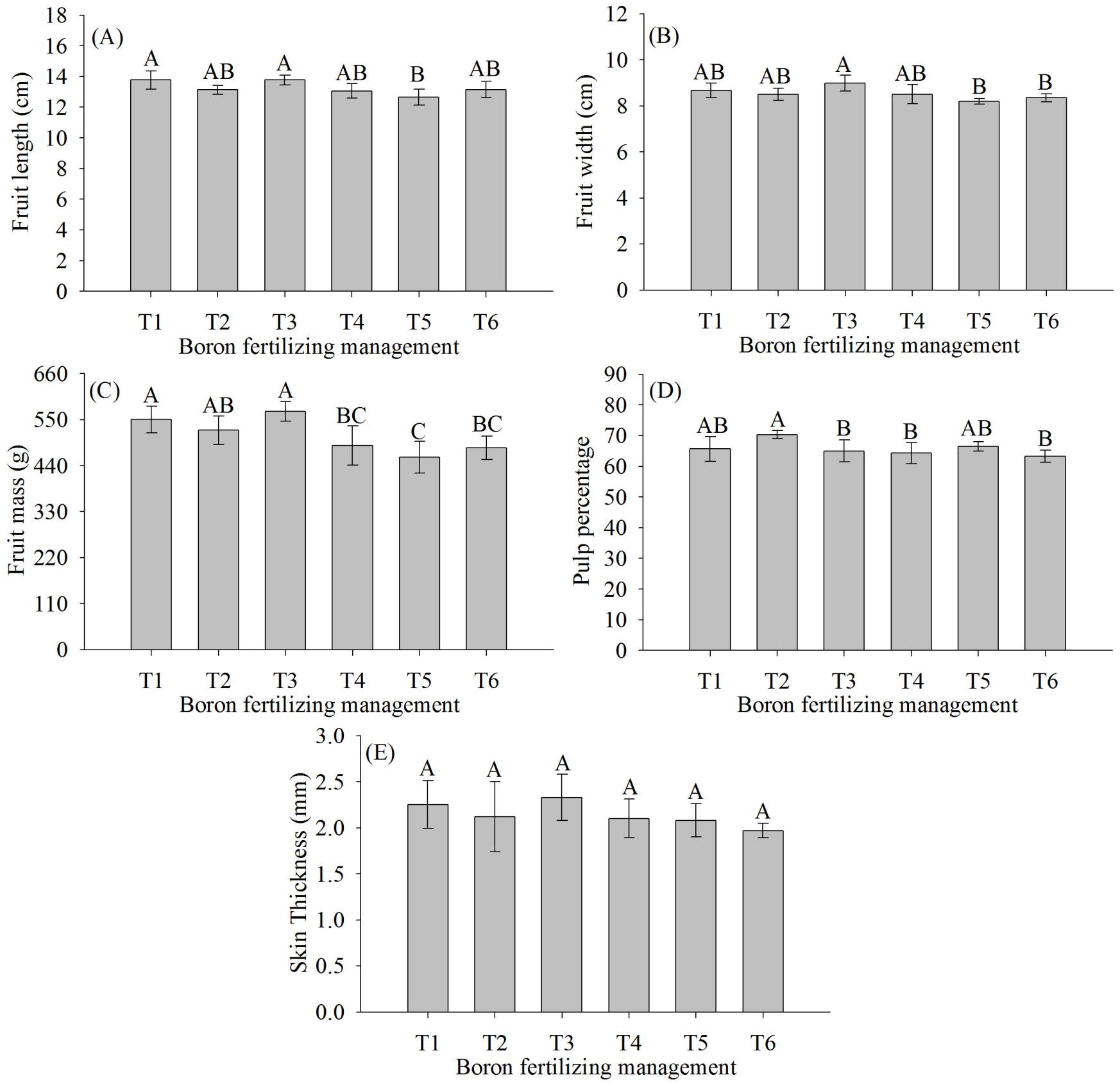

Figure 2. Fruit characteristics [length (A), fruit width (B), mass (C), pulp percentage (D) and skin thickness (E)] of mango cv. Palmer as a function of boron fertilizing management.

${ }^{(1)}$ Bars with the same capital letters do not differ in among themselves by Tukey's test at $1 \%$ probability. $\mathrm{T} 1=$ five sprays with $\mathrm{H}_{3} \mathrm{BO}_{3}$ (two first at $0.3 \%$ and three at $0.2 \%$ ); $\mathrm{T} 2=$ five sprays with $\mathrm{H}_{3} \mathrm{BO}_{3}$ (two first at $0.3 \%$ and three at $0.4 \%$ ); $\mathrm{T} 3=$ five sprays with $\mathrm{H}_{3} \mathrm{BO}_{3}$ (two first at $0.3 \%$ and three at $0.6 \%$ ); $\mathrm{T} 4=$ two sprays

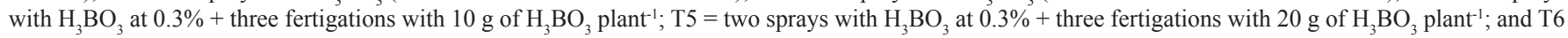
$=$ two sprays with $\mathrm{H}_{3} \mathrm{BO}_{3}$ at $0.3 \%$ + three fertigations with $40 \mathrm{~g}$ of $\mathrm{H}_{3} \mathrm{BO}_{3}$ plant ${ }^{-1}$.

Fruits from treatments that received only B leaf sprays produced higher ascorbic acid values $(\mathrm{T} 1=33.23$, $\mathrm{T} 2=29.43$ and $\mathrm{T} 3=34.21 \mathrm{mg} 100 \mathrm{~g}^{-1}$ of ascorbic acid) than other treatments $(\mathrm{T} 4=22.37, \mathrm{~T} 5=24.77$ and $\mathrm{T} 6=$

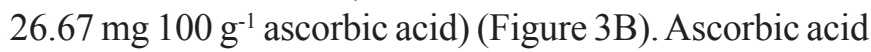
average values recorded in the present study are within the variation range reported by Machado et al. (2007) (10.78-67.67 mg $100 \mathrm{~g}^{-1}$ of ascorbic acid); but lower than

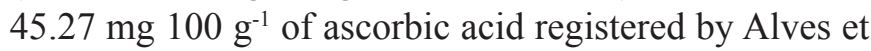
al. (2010).
In relation to the effect of B on chemical quality of fruits Mesquita et al. (2007) detach that adequate B nutrition reduces phenolic compounds levels, reduces enzymatic discoloration and significantly increases ascorbic concentration. Therefore, B presents key importance for fruit maturation since it is precursor of ascorbate, which is necessary for ACC oxidase enzyme activity, as proposed by Liu and Yang (2000).

Soluble solids (SS) contents ranged from 11.3 to $13.2^{\circ}$ Brix (Figure 3C), thus within the stated adequate quality standards defined by BRASIL (2000), whose 
minimum is $11^{\circ}$ Brix. Specifically for mango there is not enough information in the scientific literature about SS concentration as a function of B fertilizing, but for apple Sá et al. (2014) observed no effect of B on fruit SS. On the other hand, these authors affirm that leaf B spray enhanced the iodine-starch index from 3.0 (without B leaf spray) to 4.1 (with B leaf spray). Indeed, leaf boron spray promoted higher starch degradation in soluble sugars, showing anticipation of fruit maturation. Soluble solids values found in the present study are higher than $7.07^{\circ} \mathrm{Brix}$ reported by Silva et al. (2012a) for 'Palmer' mango, in São Paulo, Brazil, and compatible with those registered by Motta et al. (2015).

Pulp $\mathrm{pH}$ depended on B fertilizing management (Figure 3D), ranging from 4.46 (T5) to 4.86 (T1), thus above 4.16 reported by Carvalho et al. (2004) to 'Palmer' mango. All treatments provided $\mathrm{pH}$ values of fruits within the stated recommended range (3.3 and 4.5$)$ defined by BRASIL (2000).

In relation to SS/AT ratio, treatments T1 (68.17) and T4 (77.57) presented the highest average values when compared to the other treatments (Figure 3E). Mean values of SS/AT ratio ranged from 46.07 (T2) to 77.57 (T4). Silva et al. (2012b) verified a SS/AT ratio of 70.5 for cv. Palmer in Minas Gerais, Brazil. Accordingly, Chitarra and Chitarra (2005) argue that SS/TA ratio is one of the chemical variables commonly used to determine the fruit palatability and maturation, since it is a flavor indication, i.e., the higher SS/TA ratio the better fruit flavor.
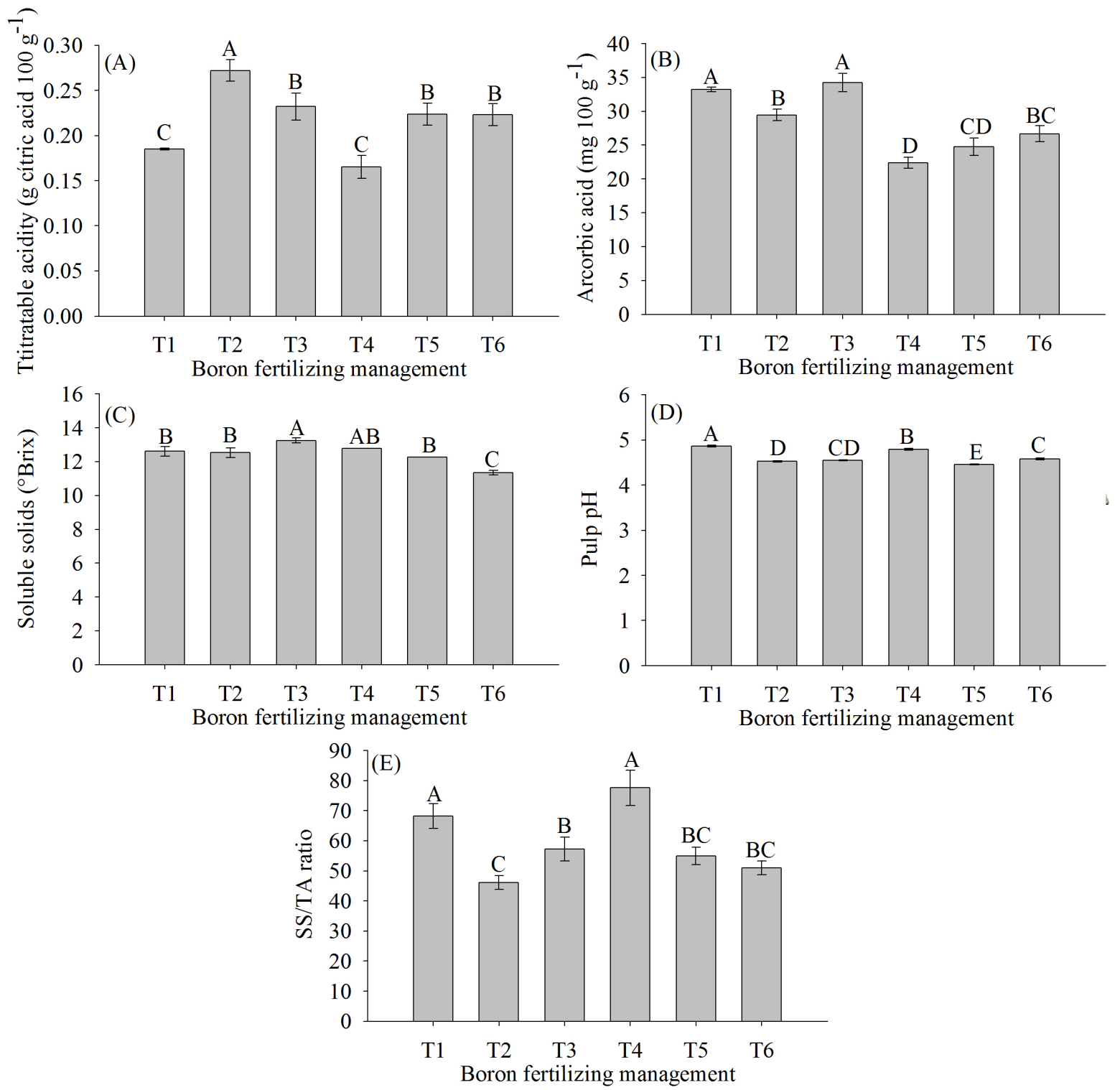

Figure 3. Chemical fruit characteristics [titratable acidity (A), ascorbic acid (B), soluble solids (C), pulp pH (D) and SS/TA ratio (E)] of mango cv. Palmer as a function of boron fertilizing management.

\footnotetext{
${ }^{(1)}$ Bars with the same capital letters do not differ in among themselves by Tukey's test at $1 \%$ probability. $\mathrm{T} 1=$ five sprays with $\mathrm{H}_{3} \mathrm{BO}_{3}$ (two first at $0.3 \%$ and three at $0.2 \%$ ); $\mathrm{T} 2=$ five sprays with $\mathrm{H}_{3} \mathrm{BO}_{3}$ (two first at $0.3 \%$ and three at $0.4 \%$ ); $\mathrm{T} 3=$ five sprays with $\mathrm{H}_{3} \mathrm{BO}_{3}$ (two first at $0.3 \%$ and three at $0.6 \%$ ); $\mathrm{T} 4=$ two sprays

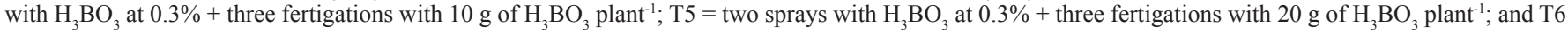

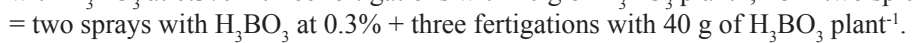




\section{Conclusion}

Boron fertilizing management (foliar spray and fertigation) affects fruit production and quality of mango cv. 'Palmer' grown in semiarid.

According to the minimum quality criteria required for mango fruit commercialization and the fruit production per plant in semiarid, five sprays with $\mathrm{H}_{3} \mathrm{BO}_{3}$ [two first at $0.3 \%$ and three at $0.2 \%$ ] could be recommended.

\section{References}

ALI, M. S.; ELHAMAHMY, M. A.; EL-SHIEKH, A. F. Mango trees productivity and quality as affected by boron and putrescine. Scientia Horticulturae, Amsterdam, v.216, p.248-255, 2017.

ALVAREZ V., V.H.; NOVAIS, R.F.; BARROS, N.F.; CANTARUTTI, R.B.; LOPES, A.S. Interpretação dos resultados das análises de solos. In: RIBEIRO, A.C.; GUIMARÃES, P.T.G.; ALVAREZ V., V.H. Recomendações para o uso de corretivos e fertilizantes em Minas Gerais. $5^{\mathrm{a}}$ aproximação. Viçosa: Comissão de Fertilidade do Solo do Estado de Minas Gerais, 1999. p.25-32.

ALVES, J.A.; NASSUR, R.C.M.R.; PIRES, C.R.F.; ALCÂNTARA, E.M.; GIANNONI, J.A.; LIMA, L.C.O. Cinética de degradação de vitamina $\mathrm{C}$ em mangas 'Palmer' minimamente processadas armazenadas em diferentes temperaturas. Ciência e Agrotecnologia, Lavras, v.34, n.3, p.714-721, 2010.

ANEES, M.; TAHIR, F.M.; SHAHZAD, J.; MAHMOOD, $\mathrm{N}$. Effect of foliar application of micronutrients on the quality of mango (Mangifera indica L.) cv. Dusehri fruit. Mycopathologia, Dordrecht, v.9, n.1, p.25-28, 2011.

BAIEA, M.H.M.; EL-BADAWY, H.E.M.; EL-GIOUSHY, S.F. Effect of potassium, zinc and boron on growth, yield and fruit quality of Keitt mango trees. Research Journal of Pharmaceutical, Biological and Chemical Sciences, Índia, v.6, n.4, p.800-812, 2015.

BARBOSA, L.F.S.; CAVALCANTE, I.H.L.; LIMA, A.M.N. Desordem fisiológica e produtividade de mangueira cv. Palmer associada à nutrição de boro. Revista Brasileira de Fruticultura, Jaboticabal, v.38, n.1, p.1-10, 2016.

BHATT, A.; MISHRA, N.; MISHRA, D.; SINGH, C. Foliar application of potassium, calcium, zinc and boron enhanced yield, quality and shelf life of mango. HortFlora Research Spectrum, Meerut, v.1, n.4, p.300-305, 2012.
BRASIL. Instrução normativa $\mathrm{n}^{\circ} 1$, de 7 de janeiro de 2000/MAPA. Regulamento técnico geral para fixação dos padrões de identidade e qualidade para polpa de frutas. Diário Oficial da União, Poder Executivo, Brasília, DF, 10 jan. 2000.

BRAZILIAN PROGRAM FOR HORTICULTURE MODERNIZATION. Standards classification of mango. São Paulo: Quality Center on Horticulture, CEAGESP), 2004. 6p. (Document, 28).

CARVALHO, C.R.L.; ROSSETTO, C.J.; MANTOVANI, D.M.B.; MORGANO, M.A.; CASTRO, J.V.; BORTOLETTO, N. Avaliação de cultivares de mangueiras selecionadas pelo Instituto Agronômico de Campinas comparada a outras de importância comercial. Revista Brasileira de Fruticultura, Jaboticabal, v.26, n.2, p.264271, 2004.

CAVALCANTE, I.H.L.; LIMA, A.M.N.; CARNEIRO, M.A.; RODRIGUEZ, M.S.; SILVA, R.L. Potassium doses on fruit production and nutrition of mango (Mangifera indica L.) cv. Palmer. Revista de la Facultad de Agronomia de la Universidad del Zulia, Maracaibo, v.34, p.385-399, 2016.

CHITARRA, M. I. F.; CHITARRA, A. B. Pós-colheita de frutas e hortaliças: fisiologia e manuseio. $2^{\text {nd }}$ ed. Lavras: UFLA, 2005. p.783.

DECHEN, A. R.; NACHTIGALL, G.R. Micronutrientes. In: FERNANDES, S.F. Nutrição mineral de plantas. Viçosa: SBCS, 2006. p.328-352.

FAO. FAOSTAT. Production-crops. Fao: Roma, 2014. Disponível em: $<$ http://faostat.fao.org/site/339/default. aspx $>$. Acesso em: 05 jun. 2016.

GALLI, J.A.; PALHARINI, M.C.A.; FISCHER, H.I.; MICHELOTTO, D.M.; MARTINS, L.M.A. Produção e qualidade de frutos de diferentes cultivares de mangueira adubadas com boro. Revista Brasileira de Ciências Agrárias, Recife, v.8, n.3, p.358-363, 2013.

GALLI, J.A.; PALHARINI, M.C.A.; FISCHER, I.H. Boro: efeito na produção e qualidade de frutos de diferentes variedades de manga. Pesquisa $\&$ Tecnologia, Campinas, v.9, n.2, p.1-4, 2012.

GENÚ, P.J. de C.; PINTO, A.C de A. A cultura da mangueira. Brasília: Embrapa Informação Tecnológica, 2002. p.452. 
LEE, S.H.; KIM, W.; HAN, T. Effects of post-harvest foliar boron and calcium applications on subsequent season's pollen germination and pollen tube growth of pear (Pyrus pyrifolia). Scientia Horticulturae, Amsterdam, v.122, p.77-82, 2009.

LIU, P.; YANG, Y. A. Effects of molybdenum and boron on membrane lipid peroxidation and endogenous protective systems of soybean leaves. Acta Botanica Sinica, Beijing, v.42, n.5, p.461-466, 2000.

MACHADO, S.S.; TAVARES, J.T.Q.; CARDOSO, R.L. Caracterização de polpas de frutas tropicais congeladas comercializadas no Recôncavo Baiano. Ciência Agronômica, Fortaleza, v.38, p.158-163, 2007.

MATTIELLO, E.M.; RUIZ, H.A.; SILVA, I.R.; BARROS, N.F.; NEVES, J.C.L.; BEHLING, M. Transporte de boro no solo e sua absorção por eucalipto. Revista Brasileira de Ciência do Solo, Viçosa, MG, v.33, p.1281-1290, 2009.

MAURER, M.A.; TAYLOR, K.C. Effect of foliar boron sprays on yield and fruit quality of navel oranges. In: WHRIGHT, G.; KILBY, M. Citrus and deciduous fruit and nut research report. Tucson: Citrus Research Council, 1999. p.1-4.

MENGEL, K.; KIRKBY, E. A.; KOSEGARTEN, H.; APPEL, T. Boron. In: MENGEL, K.; KIRKBY, E. A. Principles of plant nutrition. $5^{\text {th }}$ ed. Dordrecht: Kluwer Academic Publishers, 2001. p.621-638.

MESQUITA, H.A.; ALVARENGA, M.A.R.; PAULA, M.B.; CARVALHO, J.G.; NÓBREGA, J.C.A. Produção e qualidade da batata em resposta ao boro. Ciência e Agrotecnologia, Lavras, v.31, n.2, p.385-392, 2007.

MOTTA, J.D.; QUEIROZ, A.J.M.; FIGUEIRÊDO, R.M.F.; SOUSA, K.S.M. Índice de cor e sua correlação com parâmetros físico-químicos de goiaba, manga e mamão. Comunicata Scientiae, Bom Jesus, v.6, n.1, p.74-82, 2015.

PRADO, R.M. Nutrição e desordens fisiológicas na cultura da manga. In: ROZANE, D. E.; DAREZZO, R.J.; AGUIAR, R.L.; AGUILERA, G.H.A.; ZAMBOLIM, L. Manga - produção integrada, industrialização e comercialização. Viçosa: UFV, 2004. p.199-232.

RAJA, M.E.; KUMAR, S.C.A.; RAJU, S.Y. Boron deficiency in mango (Mangifera indica L.): A cause delineation study in acidic soils of Maharashtra. Soil Science and Plant Nutrition, Tokyo, v.5, n.5, p.751-754, 2005.
SÁ, A.A.; ERNANI, P.R.; NAVA, G.; AMARANTE, C.V.T.; PEREIRA, A.J. Influência de formas de aplicação de boro na qualidade e no rendimento de maçãs (Malus domestica). Revista Brasileira de Fruticultura, Jaboticabal, v.36, n.2, p.487-494, 2014.

SARAN, P.L.; KUMAR, R. Boron deficiency disorders in mango (Mangifera indica): field screening, nutrient composition and amelioration by boron application. Indian Journal of Agricultural Sciences, New Delhi, v.81, n.6, p.506-510, 2011.

SILVA, A.C.; SOUZA, A.P.; LEONEL, S. Growth and flowering of five mango cultivar under subtropics conditions of Brazil. American Journal of Plant Sciences, Irvine, v.5, n.3, p.393-402, 2014.

SILVA, A.C.; SOUZA, A.P.; LEONEL, S.; SOUZA, M.E.; TANAKA, A.A. Caracterização e correlação física e química dos frutos de cultivares de mangueira em São Manuel, São Paulo. Magistra, Cruz das Almas, v.24, p.15-26, 2012a.

SILVA, D.F.P.; SIQUEIRA, D.L.; ROCHA, A.; SALOMÃO, L.C.C.; MATIAS, R.G.P.; STRUIVING, T.B. Diversidade genética entre cultivares de mangueiras, baseada em caracteres de qualidade dos frutos. Revista Ceres, Viçosa, MG, v.59, p.225-232, 2012 b.

SILVA, F.C. Manual de análises químicas de solos, plantas e fertilizantes. 2.ed. Brasília: Embrapa Informação Tecnológica, 2009. p.627.

TAIZ, L.; ZEIGER, E. Fisiologia vegetal. 4.ed. Porto Alegre: Artmed, 2009. p.719.

VAlexport. Associação dos Produtores e Exportadores de Hortigranjeiros e Derivados do Vale do São Francisco. 2016. Disponível em: < $\underline{\text { http://www. }}$ valexport.com.br>. Acesso em: 05 jun. 2016.

WÓJCIK, P.; WOJCIK, M.; KLAMKOWSKI, K. Response of apple trees to boron fertilization under conditions of low soil boron availability. Scientia Horticulturae, Amsterdam, v.116, n.1, p.58-64, 2008.

ZENEBON, O.; PASCUET, N.S.; TIGLEA, P. Métodos físico-químicos para análise de alimentos. 4.ed. São Paulo: Instituto Adolfo Lutz, 2008. p.1002. 